\title{
3 Relationship between SPAD value and grain yield can be 4 affected by cultivar, environment and soil nitrogen content 5 in wheat
}

\author{
6 István Monostori · Tamás Árendás • Borbála Hoffman • Gábor Galiba • \\ 7 Krisztián Gierczik $\cdot$ Fruzsina Szira $\mathbb{D} \cdot$ Attila Vágújfalvi
}

8 Received: 25 April 2016/Accepted: 21 June 2016

9 (C) Springer Science+Business Media Dordrecht 2016

10 Abstract SPAD-502 (Minolta Ltd, Osaka Japan), a 11 hand-held chlorophyll meter is widely used in the 12 synchronization of $\mathrm{N}$ supply with actual crop demand, 13 however it is also known, that genotype and environ14 ment may effect SPAD value. Consequently, the aim of 15 this study was to evaluate the genetic and environ16 mental variation in SPAD value and to determine the 17 relationship between SPAD value at heading (GS 59) 18 and grain yield. Field experiments were conducted in 19 three consecutive cropping seasons between 2012 and 202015 in Hungary and forty winter wheat varieties were 21 tested at two nitrogen levels. Strong significant positive 22 correlation was found between grain yield and SPAD 23 values, but it was highly influenced by cultivars. The 24 proportion of the phenotypical variance explained by 25 the cultivars was different in each growing season and 26 was ranged from 12.50 to $59.04 \%$. Additionally, it was

A1 Electronic supplementary material The online version of A2 this article (doi:10.1007/s10681-016-1741-z) contains suppleA3 mentary material, which is available to authorized users.

A4 I. Monostori - T. Árendás · G. Galiba ·

A5 K. Gierczik · F. Szira $(\bowtie) \cdot$ A. Vágújfalvi

A6 Agricultural Institute, Centre for Agricultural Research,

A7 Hungarian Academy of Sciences, Brunszvik u. 2.,

A8 2462 Martonvásár, Hungary

A9 e-mail: szira.fruzsina@agrar.mta.hu

A10 B. Hoffman

A11 Department of Plant Sciences and Biotechnology,

A12 Georgikon Faculty, University of Pannonia, Deák F. u.

A13 16., 8360 Keszthely, Hungary revealed that the cultivars can be categorised by different SPAD_-yield relationship and modern cultivar can be separated into five groups. While same SPAD value can predict different yield level in different cultivars it can be concluded, that SPAD value should be calibrated for cultivar. Based on regression analysis, such an option is also presented here for forty important wheat cultivars. Hence, cultivar specific SPAD value at heading can provide a more accurate estimate of the final yield in wheat.

Keywords Wheat · Nitrogen - SPAD value . Grain yield $\cdot$ Fertilizer

\section{Introduction}

Nitrogen (N) is one of the most important limiting factors in agriculture, which implies that $\mathrm{N}$ fertilizers have significant role in helping food production keep pace with population growth (Snyder et al. 2009). Greater N application results higher yield and protein content in wheat, but it reduces farmers' profits and imposes greater risk of environmental pollution (Mary et al. 1997). Additionally, the optimal timing and rating of $\mathrm{N}$ fertilizer for a specific crop is not fixed: it may vary by cultivars, sites and years (Olfs et al. 2005). Thus, diagnostic methods providing information about plant or soil $\mathrm{N}$ status are essential for sustainable and resilient $\mathrm{N}$ management.

\begin{tabular}{|l|lll|}
\hline Journal : Medium 10681 & Dispatch : 25-6-2016 & Pages : 10 \\
Article No. : $\mathbf{1 7 4 1}$ & $\square$ LE & $\square$ TYPESET \\
MS Code : EUPH-D-16-00282 & $\checkmark \mathrm{CP}$ & $\checkmark$ DISK \\
\hline
\end{tabular}


Nowadays, indirect measurement of leaf $\mathrm{N}$ concentration, which assesses the relative greenness of the plants in a rapid and non-destructive manner is more and more popular. This approach opens the door to the continuous observation of plant $\mathrm{N}$ status, thus it helps to predict crop production and to make better nutrient management decisions.

SPAD-502 (Minolta Ltd, Osaka Japan) is an ordinarily used hand-held chlorophyll meter based on the indirect measurement of leaf chlorophyll content. It measures the leaf transmittance in red light at $650 \mathrm{~nm}$ (at which chlorophyll absorbs) and in near-infrared light at $940 \mathrm{~nm}$ (for the correction of leaf thickness). The ratio of these two transmission values is referred to as SPAD reading or SPAD value (Hoel and Solhaug 1998). Generally, SPAD measurement is performed on the first fully expanded leaf or on flag leaves at different developmental stages. Early-season readings of wheat plants provide useful information on plant nitrogen status and permit additional $\mathrm{N}$ application if necessary (Fox et al. 1994). On the other hand, SPAD readings at heading can predict grain yield in a more accurate way (Bavec and Bavec 2001).

The connection between leaf chlorophyll content determined in vitro and SPAD meter readings (SPAD values) were extensively analysed and usually parameterised by linear relationship (Wood et al. 1993; Wang et al. 2004). It is in accordance with the proportional relationship between pigment concentration and absorption predicted by Beer's Law. However, other studies report on curvilinear shape of chlorophyll-SPAD relationships (Richardson et al. 2002). Uddling et al. (2007) proved that mainly the non-uniform distribution of chlorophyll within the leaf surface is responsible for the curvilinear shape of the relationships. Furthermore, wheat showed similar SPAD-chlorophyll relationships for two different cultivars and during two different growing seasons when the chlorophyll concentration was expressed per unit leaf area and not per unit fresh weight.

It is also accepted, that a very close link exists between chlorophyll concentration and nitrogen content in the leaf (Bojovic and Markovic 2009); therefore, SPAD measurement offers a good strategy to synchronize $\mathrm{N}$ supply with actual crop demand (Islam et al. 2014). Apart from that, the impact of environment, growth stage, diurnal variation and different leaf features of crop species and genotypes on the SPADbased leaf $\mathrm{N}$ estimation were also reported (Monje and Bugbee 1992; Bavec and Bavec 2001; Xiong et al.
2015). It is also known that $\mathrm{N}$ in the chlorophyll molecules represents only about $2 \%$ of the total leaf $\mathrm{N}$ content (Lawlor et al. 2001). So, the relationship between the SPAD value and parameters refer to absolute crop $\mathrm{N}$ status (such as $\mathrm{N}$ Nutrition Index, $\mathrm{NNI}$ ) or yield is primarily based on empirical knowledge (Houlès et al. 2007).

While many authors reported the plant $\mathrm{N}$ content or NNI and SPAD relations in cereals (Giunta et al. 2002; Debaeke et al. 2006; Xiong et al. 2015; Zhao et al. 2016), studies analysing the relationship between the grain yield and the SPAD reading using numerous wheat cultivars to foresee grain yield is still limited. In a 3-year field experiment in Toulouse SPAD index and grain yield were analysed on five durum wheat cultivars (Debaeke et al. 2006). To compensate for factors other than $\mathrm{N}$ status that affect chlorophyll content normalized SPAD index were used. [The normalised SPAD index or Susceptibility Index is the ratio of any SPAD reading to the maximal value measured from plants in a fully fertilized reference plot in the same field (Wang et al. 2014)]. When $\mathrm{N}$ was a limiting factor, the normalized SPAD index measured at anthesis predicted the relative grain yield accurately. However, this method requires establishment of $\mathrm{N}$ reference strip in the field. Additionally, absolute SPAD value was characterized as cultivar-dependent (Debaeke et al. 2006). Other study on six durum wheat cultivars also revealed that SPAD value varied with cultivar, growing season and growth stages (Wang et al. 2014). Investigation of a chlorophyll meter "Hydro-N tester "value of 13 winter wheat cultivars also suggested, that readings depended on cultivar, growth stage (GS) and year (Bavec and Bavec 2001).

All study reported about the possible genotypic effect on SPAD reading in durum and winter wheat, but this impact has rarely been analysed in details. While grain weight is sensitive to post flowering environmental conditions (climate and soil $\mathrm{N}$ availability) (Denuit et al. 2002) it is interesting to test how SPAD readings are able to improve yield prediction and to what extent is this relationship affected by the genotypic variability.

Ideally, SPAD readings should only change by crop $\mathrm{N}$ status (Wang et al. 2014), but could also reflect different genotype-dependent defence mechanisms related to environmental conditions (Balla et al. 2012). Hence, SPAD value may prove to be inaccurate by diagnosing the $\mathrm{N}$ status of a given crop species in general. Therefore, relationship between SPAD

\begin{tabular}{lll} 
Journal : Medium 10681 & Dispatch : $\mathbf{2 5 - 6 - 2 0 1 6}$ & Pages : 10 \\
Article No. : $\mathbf{1 7 4 1}$ & $\square$ LE & $\square$ TYPESET \\
MS Code : EUPH-D-16-00282 & $\checkmark$ CP & $\checkmark$ DISK \\
\hline
\end{tabular}


reading and plant $\mathrm{N}$ status and/or between SPAD reading and final yield should be determined in a cultivar- and site-specific manner.

Considering the information described above, the aim of the current study was to estimate the genetic variation in SPAD reading for a great number of wheat cultivars and to evaluate how the cultivars and cropping seasons (including different soil $\mathrm{N}$ content) affect the SPAD-yield relationship. Additionally, the cropping season-dependent impact of top-dressing treatment on SPAD values was also analysed.

\section{Materials and methods}

\section{Experimental design}

Forty bread wheat varieties (Table 1) cultivated in Central Europe, mainly in Hungary, were phenotyped at MTA ATK (Centre for Agricultural Research, Agricultural Institute, Martonvásár, Hungary) during three successive cropping seasons between 2012 and 2015. Each cultivar was sown in the period of 2-21 October in a split-plot design in three replications, at two nitrogen levels. $\mathrm{N}$ treatment was considered as main plots and varieties as sub-plots. Size of each plot was $3 \times 1.44 \mathrm{~m}$ consisting of 12 rows. Prior to sowing, $45 \mathrm{~kg} / \mathrm{ha}$ phosphorus pentoxide $\left(\mathrm{P}_{2} \mathrm{O}_{5}\right)$ and $90 \mathrm{~kg} / \mathrm{ha}$ potassium oxide $\left(\mathrm{K}_{2} \mathrm{O}\right)$ was applied each year, and seed viability was determined. 500 viable seeds $/ \mathrm{m}^{2}$ were sown every year. Plots were kept clear of weeds, pests and diseases by using appropriate chemicals according to standard agricultural practise. Crops were combine-harvested at grain maturity in the period of 8-21 July and yield was expressed in t/ha.

\section{Plant material}

The 40 examined cultivars represent an elite germplasm collection grown mainly in Hungary and in Central Europe, however, some old (e.g. 'Bezostaja-1', 'Bánkúti') or non-continental (e.g. 'Nudakota') varieties are also involved (Table 1). Cultivars not owned by MTA ATK or originated from cultivar collections were obtained from companies listed in Table 1.

\section{Nitrogen regimes}

In each cropping season, the experiments were carried out at two nitrogen levels: (1) no nitrogen supply (considered as extensive management, referred to as N0), (2) intensive management whereby $120 \mathrm{~kg} \mathrm{~N}$ per hectare (referred to as N120) was applied, but in the N120 treatment, only the naturally occurring nitrogen was available in the soil. In case of N120, nitrogen was top-dressed at growth stage (GS) 21-24 (Zadoks et al. 1974). In 2014 and 2015 the fertiliser was allocated on 7 and 17 of March, respectively. In 2013, spring was cold and frosty; therefore, the $\mathrm{N}$ fertilizer could be allocated to the field only on 17 April (and at tillering stage too). In 2013, ammonium nitrate ( $34 \% \mathrm{~N})$ while in 2014 and 2015, calcium ammonium nitrate (27\% $\mathrm{N})$ was applied as fertilizer.

Experimental site

205

In the three consecutive cropping seasons, three adjacent fields belonging to the MTA ATK $\left(47^{\circ} 18^{\prime} \mathrm{N}, 18^{\circ} 48^{\prime} \mathrm{E}, 105 \mathrm{~m}\right.$ a.s.l. $)$ were used. Each spring, soil samples were collected before fertilization from two depths $(0-0.3,0.3-0.6 \mathrm{~m})$; soil mineral $\mathrm{N}$ (ammonium + nitrate) contents, and main properties of the soil were determined at an accredited laboratory (NAT-1-1093/2001 Velence, Hungary). Type of soil at each location was chernozemic but they were different concerning their available nitrogen contents Supplementary material (SM) 1. Weather data (daily rainfall and mean temperature) were recorded in Martonvásár and presented in SM 2.

SPAD measurements

SPAD measurements were performed by SPAD-502 Chlorophyll Meter (Minolta Co. Ltd., Osaka, Japan) 5 days after $50 \%$ of the genotypes had headed (GS 59). The measurements were taken on the flag leaves of five randomly selected plants within each plot. For each plant, the average of three SPAD readings around the midpoints of the flag leaves was taken.

Statistical analysis

Analysis of variance (ANOVA) for all traits was calculated using the software SPSS 16.0 for Windows (SPSS 2008). Adjusted mean of the SPAD value and yield (Fig. 1) were obtained by considering the cropping season and $\mathrm{N}$ levels as fixed factors using GLM procedure (General Linear Model). Multiple 
Table 1 Wheat varieties with winter $(\mathrm{W})$ or facultative (F) growth habits grown in Martonvásár in 2012-2015 a MTA ATK: cultivar collection at MTA ATK (Martonvásár, Hungary)

b GKI: Cereal Research Nonprofit Ltd. (Szeged, Hungary)

c Mitemag: Mitemag Ltd.(Budapest, Hungary)

d Karintia Mezőgazdasági Ltd. (Vasvár, Hungary)

e Limagrain: Limagrain Central Europe SE Ltd. (Budaörs, Hungary)

\begin{tabular}{|c|c|c|c|}
\hline Cultivar & Country of origin & Origin & Growth habit \\
\hline 'Bezostaja-1' & Russia & MTA ATK ${ }^{\mathrm{a}}$ & W \\
\hline 'Mv Apród' & Hungary & MTA ATK & W \\
\hline 'Bánkúti 1201' & Hungary & MTA ATK & W \\
\hline 'Mv Bodri' & Hungary & MTA ATK & $\mathrm{W}$ \\
\hline 'Mv Csárdás' & Hungary & MTA ATK & W \\
\hline ‘Mv Emese’ & Hungary & MTA ATK & $\mathrm{W}$ \\
\hline ‘Mv Karéj’ & Hungary & MTA ATK & W \\
\hline ‘Mv Lepény’ & Hungary & MTA ATK & W \\
\hline 'Mv Lucilla' & Hungary & MTA ATK & W \\
\hline 'Mv Magvas' & Hungary & MTA ATK & W \\
\hline 'Mv Marsall' & Hungary & MTA ATK & W \\
\hline 'Mv Mazurka' & Hungary & MTA ATK & W \\
\hline ‘Mv Menüett' & Hungary & MTA ATK & W \\
\hline ‘Mv Palotás’ & Hungary & MTA ATK & W \\
\hline ‘Mv Pengö’ & Hungary & MTA ATK & W \\
\hline 'Mv Petrence' & Hungary & MTA ATK & W \\
\hline 'Mv Regiment' & Hungary & MTA ATK & W \\
\hline ‘Mv Sobri’ & Hungary & MTA ATK & $\mathrm{W}$ \\
\hline 'Mv Suba' & Hungary & MTA ATK & $\mathrm{W}$ \\
\hline 'Mv Toborzó' & Hungary & MTA ATK & $\mathrm{W}$ \\
\hline ‘Mv Vekni' & Hungary & MTA ATK & W \\
\hline 'Jubilejnaja 50' & Russia & MTA ATK & W \\
\hline 'GK Ati' & Hungary & $\mathrm{GKI}^{\mathrm{b}}$ & $\mathrm{W}$ \\
\hline ‘GK Fény’ & Hungary & GKI & W \\
\hline ‘GK Garaboly' & Hungary & GKI & W \\
\hline ‘GK Göncöl’ & Hungary & GKI & W \\
\hline ‘GK Tisza’ & Hungary & GKI & W \\
\hline 'GK Öthalom' & Hungary & GKI & W \\
\hline 'Euclide' & France & Mitemag $^{\mathrm{c}}$ & W \\
\hline 'Josef' & Austria & Karintia $^{d}$ & $\mathrm{~W}$ \\
\hline 'Kalahari' & France & Limagrain $^{\mathrm{e}}$ & W \\
\hline 'Kinaci-97' & Turkey & MTA ATK & $\mathrm{W}$ \\
\hline 'Nudakota' & USA & MTA ATK & W \\
\hline 'Cordiale' & Germany & MTA ATK & $\mathrm{W}$ \\
\hline 'Mascot' & France & MTA ATK & W \\
\hline 'Hatcher' & USA & MTA ATK & W \\
\hline 'Mv Karizma' & Hungary & MTA ATK & $\mathrm{F}$ \\
\hline 'Krasnodarskaya—99' & Russia & MTA ATK & W \\
\hline 'Simano' & Swiss & MTA ATK & W \\
\hline 'Pitar' & Romania & MTA ATK & W \\
\hline
\end{tabular}

comparisons were made using Tukey's b test. Statistical relationship between the investigated traits was examined by regression analysis and the best fitted significant model was accepted. SPAD reaction for each cultivar was defined as SPAD N120- SPAD N0. SPAD reaction for $1 \mathrm{t} / \mathrm{ha}$ yield changes was calculated as the ratio of SPAD reaction and yield reaction (yield N120-yield N0).

\begin{tabular}{|l|lll|}
\hline Aournal : Medium 10681 & Dispatch : 25-6-2016 & Pages : 10 \\
& Article No. : 1741 & $\square$ LE & $\square$ TYPESET \\
& MS Code : EUPH-D-16-00282 & $\checkmark$ CP & $\checkmark$ DISK \\
\hline
\end{tabular}




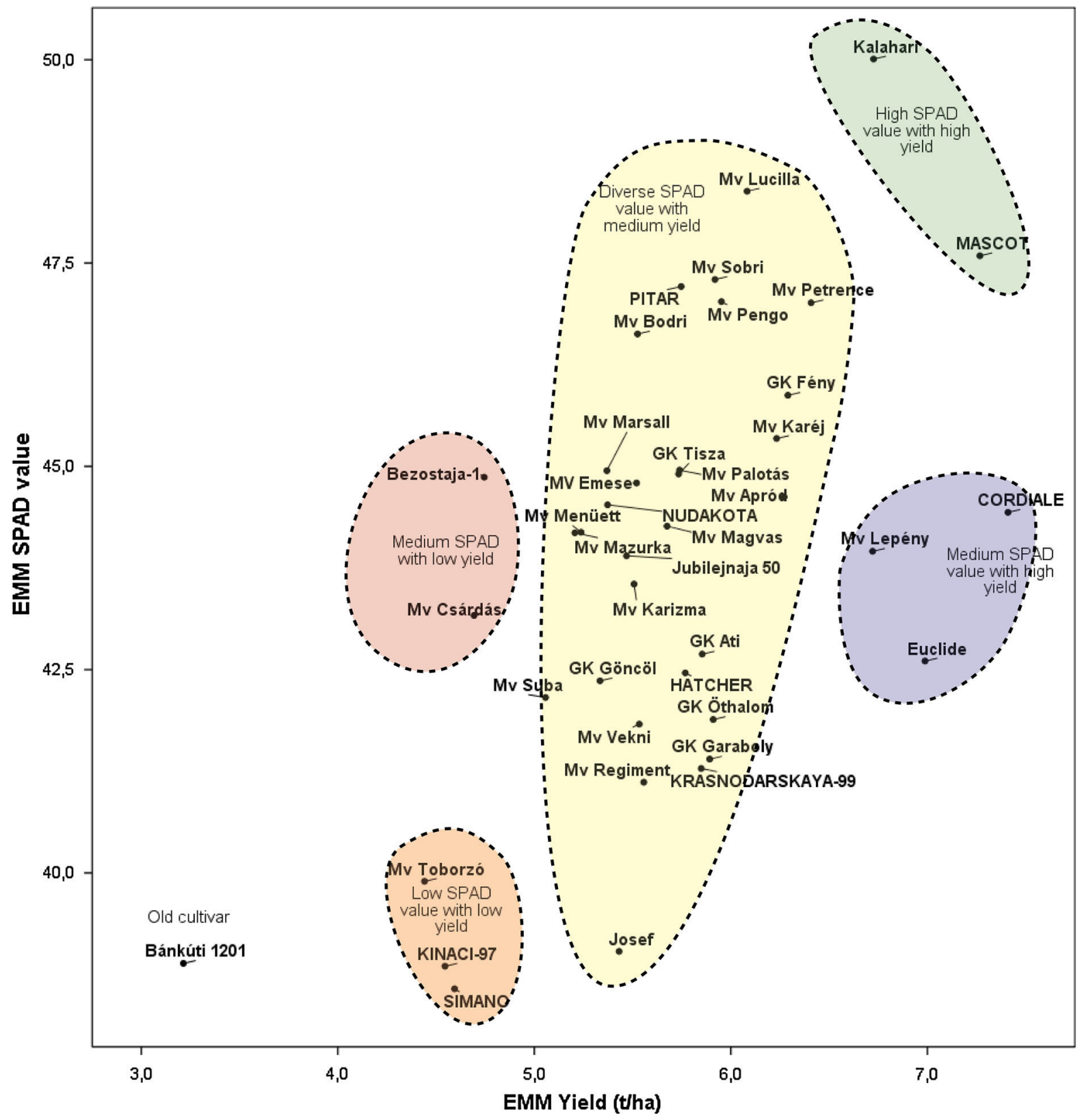

Fig. 1 Adjusted means of SPAD values and grain yields of 40 winter wheat cultivars grown in Martonvásár during three cropping seasons at two $\mathrm{N}$ levels. Each cultivar was represented by a black dot

\section{Results}

Relationships between grain yield, soil nitrogen content and SPAD value

SPAD values and grain yields of 40 winter wheat cultivars were examined during three cropping seasons. Two $\mathrm{N}$ levels ( 0 and $120 \mathrm{~kg} / \mathrm{ha}$ ) were applied and it was found that the top-dressing treatment significantly increased both the grain yields and the SPAD values each year (Table 2). However, the AQ1 50 higher the soil's $\mathrm{N}$ content was, the smaller effect of the top-dressing treatment had on both traits. Additionally, the same $\mathrm{N}$ treatment also caused

\begin{tabular}{|l|lll|}
\hline & Journal : Medium 10681 & Dispatch : 25-6-2016 & Pages : 10 \\
Article No. : $\mathbf{1 7 4 1}$ & $\square$ LE & $\square$ TYPESET \\
MS Code : EUPH-D-16-00282 & $\cup_{\mathrm{CP}}$ & $\searrow$ DISK \\
\hline
\end{tabular}


Table 2 Nitrogen content of the soil, SPAD values, SPAD reactions and yields of 40 cultivars grown in Martonvásár during three cropping seasons

\begin{tabular}{|c|c|c|c|c|c|c|c|c|c|}
\hline \multirow[t]{2}{*}{ Harvest year } & \multirow{2}{*}{$\begin{array}{l}\text { Soil } \mathrm{N}_{\text {mineral }}+\text { fertilizer } \\
(\mathrm{kgN} / \mathrm{ha})\end{array}$} & \multicolumn{3}{|c|}{ Yield (t/ha) } & \multicolumn{3}{|c|}{ SPAD values $^{1}$} & \multirow[t]{2}{*}{ SPAD reaction $^{2}$} & \multirow{2}{*}{$\begin{array}{l}\text { SPAD reaction for } \\
1 \mathrm{t} / \text { ha yield }^{3} \\
\text { change }^{3}\end{array}$} \\
\hline & & Mean & Min & $\operatorname{Max}$ & Mean & Min & $\operatorname{Max}$ & & \\
\hline \multirow[t]{2}{*}{2013} & $21+0$ & $2.82^{\mathrm{f}}$ & 1.83 & 3.5 & $32.94^{\mathrm{d}}$ & 25.08 & 41.91 & \multirow[t]{2}{*}{$9.0^{\mathrm{a}} \pm 0.56$} & \multirow[t]{2}{*}{$7.2^{\mathrm{a}} \pm 0.38$} \\
\hline & $21+120$ & $4.11^{\mathrm{e}}$ & 2.77 & 5.34 & $41.96^{\mathrm{c}}$ & 30.47 & 52.35 & & \\
\hline \multirow[t]{2}{*}{2014} & $494+0$ & $7.25^{\mathrm{b}}$ & 3.94 & 9.95 & $48.24^{\mathrm{b}}$ & 41.31 & 53.24 & \multirow[t]{2}{*}{$1.9^{c} \pm 0.26$} & \multirow[t]{2}{*}{$2.4^{\mathrm{c}} \pm 0.78$} \\
\hline & $494+120$ & $7.82^{\mathrm{a}}$ & 3.86 & 9.57 & $50.13^{\mathrm{a}}$ & 45.24 & 54.55 & & \\
\hline \multirow[t]{2}{*}{2015} & $78+0$ & $5.60^{\mathrm{d}}$ & 2.47 & 8.18 & $42.79^{c}$ & 32.91 & 50.8 & \multirow[t]{2}{*}{$4.1^{b} \pm 0.37$} & \multirow[t]{2}{*}{$4.7^{b} \pm 0.64$} \\
\hline & $78+120$ & $6.42^{\mathrm{c}}$ & 3.32 & 10.03 & $46.84^{\mathrm{b}}$ & 37.31 & 53.83 & & \\
\hline
\end{tabular}

1 Arbitrary unit of SPAD-502 (Minolta Ltd, Osaka Japan) chlorophyll meter

2 SPAD reaction was defined as mean SPAD value of cultivars at $\mathrm{N}$ level $120 \mathrm{~kg} / \mathrm{ha}$-SPAD value at $\mathrm{N}$ level $0 \mathrm{~kg} / \mathrm{ha}$

${ }^{3}$ SPAD reaction for $1 \mathrm{t} / \mathrm{ha}$ yield changes was calculated as the ratio of SPAD reaction and yield reaction (yield at $\mathrm{N}$ level $120 \mathrm{~kg} / \mathrm{ha}-$ yield level $0 \mathrm{~kg} / \mathrm{ha}$, data not shown)

significantly different grain yields in different cropping seasons. Grain yield was ranging from 1.83 to $10.03 \mathrm{t} / \mathrm{h}$ a while SPAD values were ranging from 25.1 to 54.5. The highest yields and SPAD values were obtained in 2014, when the available soil $\mathrm{N}$ content was the highest and environmental conditions also were favourable for soil $\mathrm{N}$-mineralization and plant development.

SPAD reaction (expresses the effect of the $120 \mathrm{~kg} /$ ha $\mathrm{N}$ top-dressing on the SPAD value) and SPAD reaction for $1 \mathrm{t} / \mathrm{ha}$ yield changes were calculated for each cropping season. Both of the parameters were quite different each year (Table 2). These two parameters were in inverse ratio to the soil $\mathrm{N}$ level. Regression analysis revealed a significant logarithmic relation between SPAD value and soil $\mathrm{N}$ mineral $\left(\mathrm{N}_{\text {min }}\right)$ content $\left(R^{2}=0.929, P<0.001, \mathrm{y}=4.7803\right.$ $\ln (\mathrm{x})+19.708)$ and also between SPAD reaction and soil $\mathrm{N}_{\text {min }}$ content $\left(R^{2}=0.512, \quad P<0.001\right.$, $\mathrm{y}=-2.183 \ln (\mathrm{x})+15.055)$. Besides, exponential relationship was found between SPAD reaction for $1 \mathrm{t} /$ ha yield and soil $\mathrm{N}_{\min }$ content $\left(R^{2}=0.276\right.$, $\left.P<0.001, \mathrm{y}=6.4649 \mathrm{e}^{-0.002 \mathrm{x}}\right)$.

Significant positive relationship was found between the grain yields and SPAD values of the 40 winter wheat cultivars each year (Table 3 ). The strongest relation $\left(R^{2}=0.617, P<0.001\right)$ was observed in 2013 while in 2014 only $18 \%$ of the total variance observed in the yield corresponded to the above relationship. However, the analysis of the 3-year data revealed an exponential relation between grain yields and SPAD values.
Variance components of the SPAD value

Analysis of variance revealed that SPAD values were significantly affected by $\mathrm{N}$ treatment and cultivars in each case (Table 4). Considering the period between 2013 and 2015, most of the variance was caused by the cropping season (i.e. difference in weather and soil $\mathrm{N}_{\text {min }}$ conditions). Additionally, the Year $\times \mathrm{N}$ treatment and the Year $\times$ Cultivar interaction were also significant but only in case of lower sum of squares. The ratio of genetic variance (cultivar effect) in the total phenotypic variation for SPAD values was highly variable among cropping seasons and was ranged between $21.7 \%$ and $59.1 \%$. It was also observed that the smaller was the phenotypic variance explained by the $\mathrm{N}$ treatment, the bigger was the variance explained by the cultivar. In 2013, when the lowest soil $\mathrm{N}_{\min }$ was measured (SM 1), most of the phenotypic variance was caused by $\mathrm{N}$ treatment (38.8\%). Hence, in 2014 and 2015 , cultivar was the main source of variance.

Cultivar dependent SPAD-yield relationship

Based on our dataset (3 years $\times 2 \mathrm{~N}$ levels), SPADyield distribution of the 40 cultivars were also analysed (Fig. 1). It was demonstrated that the cultivars were separated into five groups. Most cultivars (29) belong to a diverse group described by different SPAD values and medium (5-6 t/ha) grain yields but other cultivars represent distinct SPAD-yield characteristics. The old cultivars 'Bezostaja-1' and ' $\mathrm{Mv}$ Csárdás' can be separated by medium SPAD values
306

307

308

309

310

311

312

313

314

$\begin{array}{lll}\text { Journal : Medium 10681 } & \text { Dispatch : 25-6-2016 } & \text { Pages : 10 } \\ \text { Article No. : } \mathbf{1 7 4 1} & \square \text { LE } & \square \text { TYPESET } \\ \text { MS Code : EUPH-D-16-00282 } & \checkmark_{\mathrm{CP}} & \checkmark \text { DISK }\end{array}$


Table 3 Correlations and regression curves for the estimation of grain yield based on SPAD values of 40 winter wheat cultivars in a three-year experiment in Martonvásár

\begin{tabular}{lllll}
\hline Harvest year & $R^{2 \mathrm{a}}$ & $P$ value & Best fitted model & Equation \\
\hline 2013 & 0.617 & $<0.001$ & Linear & $\mathrm{y}=0.1104 \mathrm{x}-0.6694$ \\
2014 & 0.185 & $<0.001$ & Linear & $\mathrm{y}=0.1703 \mathrm{x}-0.8411$ \\
2015 & 0.461 & $<0.001$ & Linear & $\mathrm{y}=0.2119 \mathrm{x}-3.4857$ \\
$2013-2015$ & 0.746 & $<0.001$ & Exponential & $\mathrm{y}=0.5423 \mathrm{e}^{0.0519 \mathrm{x}}$ \\
\hline
\end{tabular}

${ }^{2}$ coefficient of determination

Table 4 Analysis of variance for SPAD values based on 40 wheat cultivars grown in Martonvásár at two N levels between 2013 and 2015

\begin{tabular}{|c|c|c|c|c|c|c|c|c|c|}
\hline \multirow[t]{2}{*}{ Source of variation } & \multirow[t]{2}{*}{$d f^{a}$} & \multicolumn{4}{|c|}{ Mean squares } & \multicolumn{4}{|c|}{$P$ value } \\
\hline & & 2013 & 2014 & 2015 & 2013-2015 & 2013 & 2014 & 2015 & 2013-2015 \\
\hline Cultivar (C) & 39 & 69.02 & 41.36 & 88.91 & 133.31 & $<0.001$ & $<0.001$ & $<0.001$ & $<0.001$ \\
\hline $\mathrm{N}$ levels $(\mathrm{N})$ & 1 & 4820.82 & 213.35 & 979.07 & 4440.96 & $<0.001$ & $<0.001$ & $<0.001$ & $<0.001$ \\
\hline Year (Y) & 2 & - & - & - & 8350.69 & - & - & - & $<0.001$ \\
\hline $\mathrm{C} \times \mathrm{N}$ interaction & 39 & 18.66 & 4.15 & 8.28 & 13.66 & NS & NS & NS & NS \\
\hline $\mathrm{C} \times \mathrm{Y}$ interaction & 78 & - & - & - & 32.75 & - & - & - & $<0.01$ \\
\hline $\mathrm{N} \times \mathrm{Y}$ interaction & 2 & - & - & - & 793.52 & - & - & - & $<0.001$ \\
\hline Error & $474,476^{\mathrm{b}}$ & 26.27 & 4.59 & 30.19 & 20.33 & & & & \\
\hline
\end{tabular}

a $d f$ degree of freedom

b Degree of freedom for the 3-year dataset (2013-2015)

(43-45) with low ( $<5$ t/ha) grain yield. 'Mv Lepény', 'Euclide' and 'Cordiale' showed medium SPAD values too but an average of $7 \mathrm{t} / \mathrm{ha}$ grain yield was achieved. 'Kalahari' and 'Mascot' represent high SPAD values (48-50) with high yielding cultivars; contrarily 'Mv Toborzó', 'Kinachi-97' and 'Simano' represent low SPAD values (39-41) with low yielding cultivars. 'Bánkúti 1201' was separated from all other cultivars and showed the lowest yield and SPAD value.

SPAD-yield dataset of four interesting cultivars with different characteristics are shown in Fig. 2 while regression equation of all forty cultivars weas presented in SM3. Similarly to the Fig. 1, different SPAD-yield characteristics were identified in the case of different cultivars. These four selected cultivars represent variant characteristics. The slope of the fitted equation was similar in case of 'Bánkúti 1201' and 'Bezostaja-1' but the latter has higher grain yield and SPAD value in all cases. Since significantly higher maximum yields and SPAD values were achieved by
'Kalahari' and 'Mv Lepény', fitted equation showed bigger slope compared to 'Bánkúti 1201' and 'Bezostaja 1'. Cultivar reaching the highest SPAD value was 'Kalahari', while 'Mv Lepény' was the best yielding. Distribution of the data points belonging to 'Bánkúti 1201' was balanced between the minimum and maximum values. Contrarily, in the case of 'Bezostaja-1', 'Mv Lepény' and 'Kalahari', the distribution was unbalanced suggesting that these cultivars have reached their maximum SPAD and yield values in the examined environments.

\section{Discussion}

Many studies indicate that SPAD-502, a portable chlorophyll meter is an appropriate tool to simply and quickly diagnose plant $\mathrm{N}$ status in wheat (Giunta et al. 2002; Szabó 2014). However, it was also published that the relationship between SPAD value and the plant $\mathrm{N}$ status or yield may vary depending on

\begin{tabular}{|l|lll|}
\hline & Journal : Medium 10681 & Dispatch : 25-6-2016 & Pages : $\mathbf{1 0}$ \\
Article No. : $\mathbf{1 7 4 1}$ & $\square \mathrm{LE}$ & $\square$ TYPESET \\
& MS Code : EUPH-D-16-00282 & $\cup_{\mathrm{CP}}$ & $\checkmark$ DISK \\
\hline
\end{tabular}




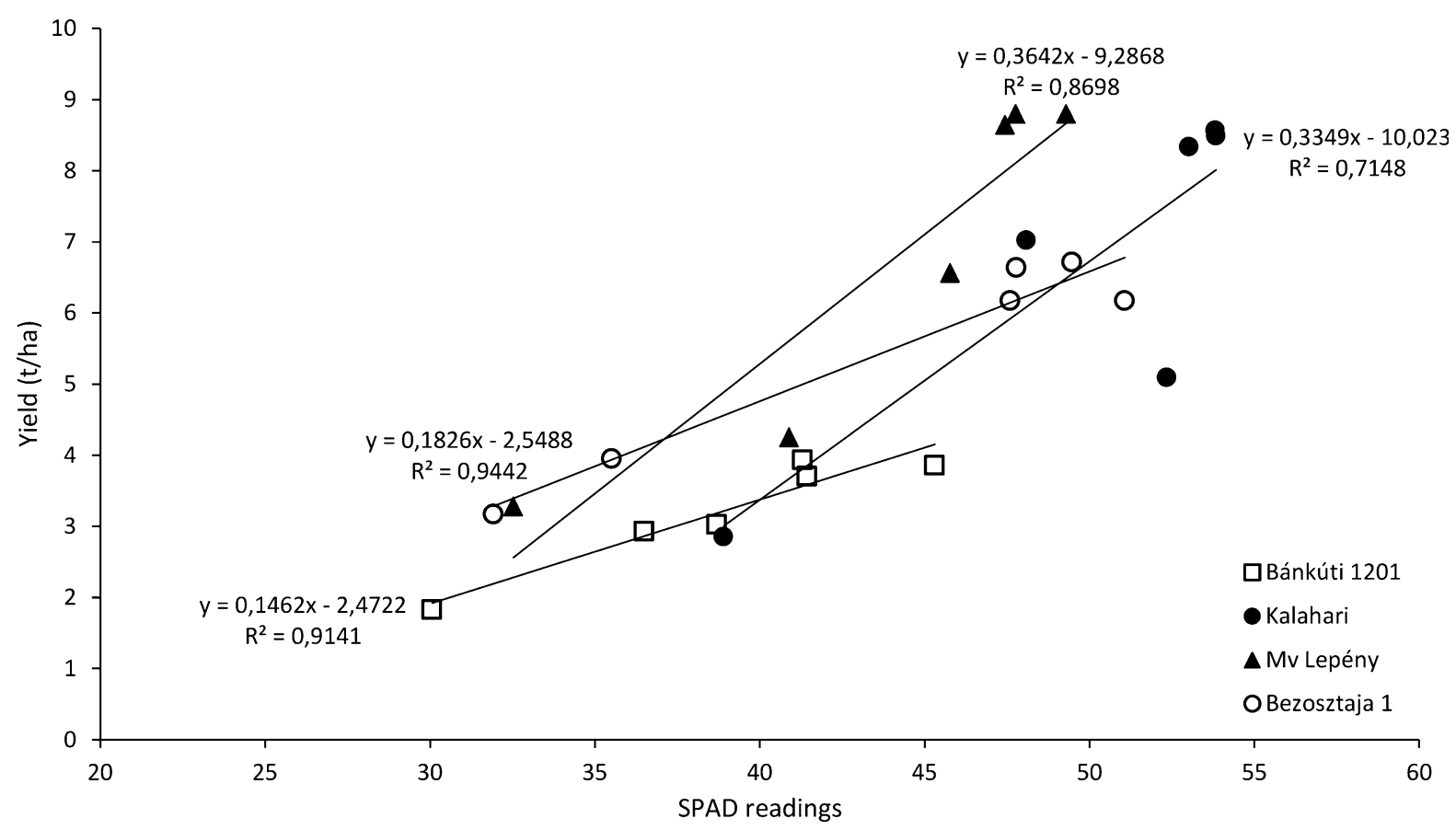

Fig. 2 Cultivar-specific relationship between grain yields and SPAD readings. Data points show the average of three replications measured under each condition $(3$ year $\times 2 \mathrm{~N}$ level)

cultivars and environments (Debaeke et al. 2006; Bavec and Bavec 2001).

Therefore, some authors recommend the use of normalized SPAD value or specific leaf weight (SLW, leaf dry weight $(\mathrm{mg}) /$ produced leaf area $\left(\mathrm{cm}^{2}\right) /$ plant $)$ instead of SPAD value to increase the accuracy of prediction (Peng et al. 1993; Debaeke et al. 2006; Yuan et al. 2016). It was also concluded that the standardization of the SPAD measurement demands further testing due to the possible effect of the cultivars (Peng et al. 1993). Unfortunately, these indicators (normalized SPAD and SLW) require absolute N content determination or fully fertilized control plot, which brakes off the simplicity and rapidity of SPAD measurement. In order to improve the estimation capability of the SPAD measurement, it is necessary to take the differences arising from the diversity of the cultivars into account.

In most of the publications, only a few (four-five) genotypes or varieties were tested (Yuan et al. 2016; Zhao et al. 2016) but some of them involved more (13-25) cultivars (Bavec and Bavec 2001; Y1ldirım et al. 2010). In this study, non-adjusted SPAD values of 40 wheat cultivars were analysed. It was revealed that the main source of variance was the year, but the $\mathrm{N}$ level and cultivar also had significant effect on SPAD values (Table 4). Other investigation on winter wheat also suggested that the chlorophyll meter (CM) reading depends on cultivar and year (Bavec and Bavec 2001). Additionally, significant variance was attributed to the cultivar in durum wheat and its ratio in the total variation was between 16.8 and $27.3 \%$ (Yildirim et al. 2010). In this study, considering the 3-year dataset for 40 genotypes, a lower, $12.5 \%$ variance of the cultivars was observed. Significant Year $\times \mathrm{N}$ level interaction was also revealed by the analysis and showed, that the same level of the $\mathrm{N}$ fertilizer can caused different SPAD value in different year. While the data was reported from years differing for monthly temperature, precipitation and soil $\mathrm{N}_{\text {min }}$ level, it can be concluded that different soil $\mathrm{N}_{\text {min }}$ level is also significant source of the variance. Based on this, it can be confirmed that both cultivar and environment have notable effect on SPAD readings.

Logarithmic and exponential relation between different SPAD values (SPAD value, SPAD reaction, SPAD reaction for $1 \mathrm{t} /$ ha yield) and soil $\mathrm{N}$ mineral $\left(\mathrm{N}_{\min }\right)$ content was also found. In each year same level of $\mathrm{N}$ fertilizer was applied and higher the soil $\mathrm{N}_{\min }$ was, the less the SPAD value, the SPAD reaction and

\begin{tabular}{|l|lll|}
\hline & Journal : Medium 10681 & Dispatch : 25-6-2016 & Pages : 10 \\
Article No. : 1741 & $\square$ LE & $\square$ TYPESET \\
MS Code : EUPH-D-16-00282 & $\checkmark$ CP & $\checkmark$ DISK \\
\hline
\end{tabular}


SPAD reaction for $1 \mathrm{t} / \mathrm{ha}$ yield have changed. This coincide the results previously observed: in the situation where $\mathrm{N}$ was a main factor limiting crop production SPAD index around anthesis was a suitable predictor for grain yield (Bavec and Bavec 2001; Wang et al. 2014), but it was less applicable, when wheat was grown under well- or over-fertilized regime (Debaeke et al. 2006).

In most studies on cereal crops, significant variation in SPAD meter readings among growth stages were also mentioned (Le Bail et al. 2005; Debaeke et al. 2006; Wang et al. 2014). Additionally, in stem elongation stage no significant correlation was found between chlorophyll meter values and grain yield, but there was significant quadratic relationship at booting stage (Bavec and Bavec 2001). More accurate yield prediction based on the SPAD readings at heading than at grain filling was found by Yildirim et al. (2010). It was published also, that the CM reading showed no strong correlation with grain yield at an early stage (GS 31-32) but $37 \%$ of the variance in grain yield was possible to explain with SPAD reading (Bavec and Bavec 2001) at a later stage (GS 55-75). In this study, on the basis of SPAD values of 40 cultivars at the stage GS 59/60, up to $75 \%$ of the total variation in yields could be explained by the relationship between grain yield and SPAD value. All results indicate that SPAD measurement of flag leaves is a valuable approach for yield prediction in wheat, and the relationship is stronger in the reproductive stage than in the early stage. However, no detailed analysis on cultivar effect has been presented so far.

In this study, SPAD values and grain yields of 40 wheat cultivars were analysed. Due to the unfavourable weather and soil conditions, the lowest yields and SPAD values were measured in 2013. Křen et al. (2015) also reported that in 2013, the differentiation of tillers was delayed in barley and their productivity decreased because sufficient number of strong tillers at the beginning of vegetation is needed for effective use of inputs and high yield. The experimental field of the study above is located about $300 \mathrm{~km}$ far from the field in Martonvásár.

The analysis of the SPAD-yield data also revealed that the cultivars can be categorised by different SPAD_yield relationships. 'Bánkúti 1201' showed very low SPAD value and grain yield, and was separated from all other cultivars. Separation was supposedly due to the fact that 'Bánkúti 1201' is an old, tall and extensive cultivar with very high grain protein content. For this reason, it is still involved in breeding programs in Hungary. The "low SPAD value with low yield group" consists of three cultivars. Among these 'Mv Toborzó' is a very early flowering and high quality wheat with extraordinary developmental rhythm. It is supposed that 'Mv Toborzó' belongs to this group due to the standardised and not cultivar specific agrotechnical practice applied in this experiment. After 'Bánkúti 1201', 'Bezostaja-1' was the dominant cultivar in Hungary between 1960 and 1975; with 'Mv Csárdás' they represent a medium SPAD group with low yield. This is a hard grain wheat cultivar; based on the official recommendation, it has stable gluten content. The biggest group is characterised by $\sim 5.5 \mathrm{t} /$ ha yield and diverse SPAD values. The two extreme SPAD values of 39.0 and 48.3 within this group belong to 'Josef' and 'Mv Lucilla', respectively. 'Mv Lucilla' can be described by its good adaptation capacity while 'Josef', an Austrian cultivar, is characterised by high protein content. 'Josef' is a good example that a cultivar bred for premium quality does not necessarily have high SPAD value. Based on the data of this 3-year experiment applying two $\mathrm{N}$ levels, five cultivars showed higher than $6.5 \mathrm{t} / \mathrm{ha}$ grain yield in average. At this yield level, 'Kalahari' and 'Mascot' represent the high SPAD value group (with the average value of 48.5) while 'Mv Lepény', 'Cordiale' and 'Euclide' showed lower SPAD value (with the average value of 42.6). Among these five cultivars, 'Mv Lepény' is a soft grain wheat (nabim Group 3) while others are high yielding milling cultivars (nabim Group 2).

Based on these results it can be concluded that SPAD values should be calibrated for the cultivars and more accurate $\mathrm{N}$ diagnosis and yield prediction can be provided to farmers if the relationship between SPAD value and grain yield is characterized in a cultivar specific manner. Since the 40 wheat cultivars investigated herein represent mainly elite germplasm, the cultivar-specific SPAD-yield correlation presented in SM 3 can be used as practical guide in the SPADbased yield prediction around heading in Central Europe.

Acknowledgments This work was supported by the Hungarian Research Fund (Országos Tudományos Kutatási Alap OTKA K101794) and authors would like to thank you to Mónika E. Fehér and Imréné Horváth for their excellent technical assistance.

\begin{tabular}{|l|lll|}
\hline Aournal : Medium 10681 & Dispatch : 25-6-2016 & Pages : 10 \\
Article No. : 1741 & $\square$ LE & $\square$ TYPESET \\
MS Code : EUPH-D-16-00282 & $\checkmark$ CP & $\checkmark$ DISK \\
\hline
\end{tabular}




\section{References}

503

504

505

506

507

508

509

510

511

512

513

514

515
Balla K, Karsai I, Kiss T, Bencze S, Bedő Z, Veisz O (2012) Productivity of a doubled haploid winter wheat population under heat stress. Open Life Sci. doi:10.2478/s11535-0120097-1

Bavec F, Bavec M (2001) Chlorophyll meter readings of winter wheat cultivars and grain yield prediction. Commun Soil Sci Plant Anal 32:2709-2719. doi:10.1081/CSS-120000956

Bojović B, Marković A (2009) Correlation between nitrogen and chlorophyll content in wheat (Triticum aestivum L.). Kragujev J Sci 31:69-74

Debaeke P, Rouet P, Justes E (2006) Relationship between the normalized SPAD index and the nitrogen nutrition index: application to durum wheat. J Plant Nutr 29:75-92. doi:10. 1080/01904160500416471

Denuit J-P, Olivier M, Goffaux M-J, Herman J-L, Goffart J-P, Destain J-P, Frankinet M (2002) Management of nitrogen fertilization of winter wheat and potato crops using the chlorophyll meter for crop nitrogen status assessment. Agronomie 22:847-853. doi:10.1051/agro:2002065

Fox RH, Piekielek WP, Macneal KM (1994) Using a chlorophyll meter to predict nitrogen fertilizer needs of winter wheat. Commun Soil Sci Plant Anal 25:171-181. doi:10. 1080/00103629409369027

Giunta F, Motzo R, Deidda M (2002) SPAD readings and associated leaf traits in durum wheat, barley and triticale cultivars. Euphytica 125:197-205

Hoel BO, Solhaug KA (1998) Effect of irradiance on chlorophyll estimation with the Minolta SPAD-502 leaf chlorophyll meter. Ann Bot 82:389-392. doi:10.1006/anbo.1998. 0683

Houlès V, Guérif M, Mary B (2007) Elaboration of a nitrogen nutrition indicator for winter wheat based on leaf area index and chlorophyll content for making nitrogen recommendations. Eur J Agron 27:1-11. doi:10.1016/j.eja. 2006.10.001

Islam MR, Haque KMS, Akter N, Karim MA (2014) Leaf chlorophyll dynamics in wheat based on SPAD meter reading and its relationship with grain yield. Sci Agric 4:13-18. doi:10.15192/PSCP.SA.2014.4.1.1318

Křen J, Klem K, Svobodová I, Mîša P, Lukas V (2015) Influence of sowing, nitrogen nutrition and weather conditions on stand structure and Yield of spring barley. Cereal Res Commun 43:326-335. doi:10.1556/CRC.2014.0036

Lawlor DW, Lemaire G, Gastal F (2001) Plant nitrogen. Springer, Berlin Heidelberg, Berlin, Heidelberg

Le Bail M, Jeuffroy M-H, Bouchard C, Barbottin A (2005) Is it possible to forecast the grain quality and yield of different varieties of winter wheat from Minolta SPAD meter measurements? Eur J Agron 23:379-391. doi:10.1016/j.eja. 2005.02.003

3 Mary B, Beaudoin N, Benoit M (1997) Prevention of nitrogen pollution in watersheds. Control Nitrogen Conc Agrosystems $289-312$

Monje OA, Bugbee B (1992) Inherent limitations of nondestructive chlorophyll meters: a comparison of two types of meters. HortScience 27:69-71
Olfs HW, Blankenau K, Brentrup F, Jasper J, Link A, Lammel J (2005) Soil- and plant-based nitrogen-fertilizer recommendations in arable farming. J Plant Nutr Soil Sci 168:414-431. doi:10.1002/jpln.200520526

Peng S, Garcia F, Laza R, Cassman K (1993) Adjustment for specific leaf weight improves chlorophyll meters estimate of rice leaf nitrogen concentration. Agron J 85:987-990

Richardson AD, Duigan SP, Berlyn GP (2002) An evaluation of noninvasive methods to estimate foliar chlorophyll content. New Phytol 153:185-194. doi:10.1046/j.0028-646X. 2001.00289.x

Snyder CSS, Bruulsema TWW, Jensen TLL, Fixen PEE (2009) Review of greenhouse gas emissions from crop production systems and fertilizer management effects. Agric Ecosyst Environ 133:247-266. doi:10.1016/j.agee.2009.04.021

Szabó É (2014) Effect of some physiological properties on the quality parameters of different winter wheat varieties in a long-term experiment. Cereal Res Commun 42:126-138. doi:10.1556/CRC.2013.0048

Uddling J, Gelang-Alfredsson J, Piikki K, Pleijel H (2007) Evaluating the relationship between leaf chlorophyll concentration and SPAD-502 chlorophyll meter readings. Photosynth Res 91:37-46. doi:10.1007/s11120-006-90775

Wang Q, Chen J, Li Y (2004) Nondestructive and rapid estimation of leaf chlorophyll and nitrogen status of peace lily using a chlorophyll meter. J Plant Nutr 27:557-569. doi:10. 1081/PLN-120028878

Wang G, Bronson KF, Thorp KR, Mon J, Badaruddin M (2014) Multiple leaf measurements improve effectiveness of chlorophyll meter for durum wheat nitrogen management. Crop Sci 54:817-826. doi:10.2135/cropsci2013.03.0160

Wood CW, Reeves DW, Himelrick DG (1993) Relationships between chlorophyll meter readings and leaf chlorophyll concentration, $\mathrm{N}$ status, and crop yield: a review. Proc Agron Soc New Zeal 23:1-9

Xiong D, Chen J, Yu T, Gao W, Ling X, Li Y, Peng S, Huang J (2015) SPAD-based leaf nitrogen estimation is impacted by environmental factors and crop leaf characteristics. Sci Rep 5:1-12. doi:10.1038/srep13389

Yıldırım M, Kılıç H, Kendal E, Karahan T (2010) Applicability of chlorophyll meter readings as yield predictor in durum wheat. J Plant Nutr 34:151-164. doi:10.1080/01904167. 2011.533319

Yuan Z, Ata-Ul-Karim ST, Cao Q, Lu Z, Cao W, Zhu Y, Liu X (2016) Indicators for diagnosing nitrogen status of rice based on chlorophyll meter readings. F Crop Res 185:12-20. doi:10.1016/j.fcr.2015.10.003

Zadoks JC, Chang TT, Konzak CF (1974) A decimal code for the growth stages of cereals. Weed Res 14:415-421. doi:10.1111/j.1365-3180.1974.tb01084.X

Zhao B, Liu Z, Ata-Ul-Karim ST, Xiao J, Liu Z, Qi A, Ning D, Nan J, Duan A (2016) Rapid and nondestructive estimation of the nitrogen nutrition index in winter barley using chlorophyll measurements. F Crop Res 185:59-68. doi:10. 1016/j.fcr.2015.10.021

\begin{tabular}{|l|lll|}
\hline & Journal : Medium 10681 & Dispatch : 25-6-2016 & Pages : 10 \\
Article No. : 1741 & $\square$ LE & $\square$ TYPESET \\
MS Code : EUPH-D-16-00282 & $\checkmark_{\mathrm{CP}}$ & $\checkmark$ DISK \\
\hline
\end{tabular}


Journal : 10681

Article : 1741

\section{算 Springer}

the language of science

\section{Author Query Form}

\section{Please ensure you fill out your response to the queries raised below and return this form along with your corrections}

Dear Author

During the process of typesetting your article, the following queries have arisen. Please check your typeset proof carefully against the queries listed below and mark the necessary changes either directly on the proof/online grid or in the 'Author's response' area provided below

\begin{tabular}{|l|l|l|}
\hline Query & Details Required & Author's Response \\
\hline AQ1 & Please provide a definition for the significance of letters 'a-f' in the Table 2. & \\
\hline AQ2 & kindly check and confirm Edit made in the article title in the reference Denuit et al (2002). & \\
\hline AQ3 & Please provide the complete details for the reference Mary et al. (1997). & \\
\hline
\end{tabular}

